\title{
The effect of knowledge management on organizational innovation: Evidence from banking industry
}

\author{
Ali Valipour ${ }^{\mathrm{a}}$, Mohammad Pasandidehfar ${ }^{\mathrm{b}}$, and Vida Rahim Hashemabadi ${ }^{*}$
}

\begin{tabular}{l}
\hline C H R O N I C L E \\
\hline Article history: \\
Received September 5, 2016 \\
Received in revised format \\
November 112016 \\
Accepted January 102016 \\
Available online \\
January 112017 \\
\hline Keywords: \\
Knowledge management \\
Empowerment \\
Innovation \\
Agricultural Bank of Iran
\end{tabular}

a Department of Management \& Accounting (Marketing Ph.D group), Abhar Branch Islamic Azad University, Abhar, Iran

${ }^{b}$ Department of Management \& Accounting (Accounting group), Science \& Research Branch Islamic Azad University, Shahre-Qods, Iran ${ }^{c}$ Faran Mehr Danesh Virtual Institute for Higher Education, Tehran, Iran

\section{Introduction}

The rapid development of high technology, information and communications technologies have urged many organizations to seek actively for new ways, ideas, experimentations, and creative solutions in improving their current products, processes, systems and technologies, commonly referred as organizational innovation. (Tan \& Nasurdin, 2011). The learning process occurs to improve the stock of knowledge available to the organization and to amplify the value of its intellectual assets, such as innovation capital when knowledge is acquired and applied. If an organization demonstrates competence in knowledge management, it can be considered as having a knowledge managementorientation (Darroch \& McNaughton, 2002).

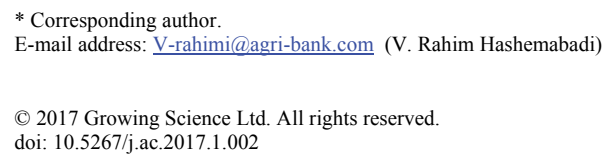


Knowledge management has been broadly defined from different perspectives. Wiig (1997) viewed as a set of activities that lead an organization in acquiring knowledge both internally and externally. According to Salisbury (2003), knowledge management is defined as the deployment of a comprehensive system that enhances the growth of an organization's knowledge. In an effort to expand the knowledge management discipline, knowledge management can be defined as the management functions that encompass the creation of knowledge, management of the flow of knowledge within the organization, and usage of knowledge in an effective and efficient manner for the long-term benefit of the organization (Darroch \& McNaughton, 2002). Hence, knowledge management effectiveness is regarded as a management discipline, which focuses on the development and usage of knowledge to support the achievement of strategic business objectives.

\section{Literature review}

The recognition of market opportunities is very important towards appropriate positioning in order to achieve competitive advantage. Investigating these opportunities through innovative ways needs special knowledge, creative ideas, and the capability to recognize user/customer decision making and practical thoughts (Nonaka \& Toyama, 2007). Based on those requirements, the ability to recognize opportunities partly relies on the people's learning capabilities and extant knowledge (Teece, 2007). Today's organizations are interested in stimulating knowledge, which is the biggest possible asset of organizations (Akgun et al., 2007). The growing interest in organizational knowledge has highlighted the managing the knowledge to the organization's advantage as well (Alavi \& Leidner, 1999). Therefore, the concept of Knowledge Management (KM) draws a substantial interest and various definitions of KM have appeared in the extant literature. According to Davenport (1996), KM is either a philosophical or a technological level, with little pragmatic discussion on how knowledge can be managed and implemented. The best utilization of the organizational knowledge, though, has been determined by Parlby and Taylor (2000), as a vehicle, which backs innovation, creates new ideas and exploits the organization's thinking power. Moreover, the process of managing organizational knowledge has been considered in terms of value creation through organizational intangible assets. According to Malhotra (1997), KM is a regulative principle aimed to meet customer expectations. She also recommends that by providing the right knowledge to the right people at the right time, KM methods make it possible for organizations to design dynamic processes and to exploit their human resources, efficiently. The latter rationale discloses a hidden concept of collective knowledge referred by von Krogh (1998) in his argument that KM detects the collective knowledge in a firm to help this organization compete. Some people exploit the notion of collective knowledge together with the corporate knowledge to explain KM as the process in which organizations create and make use of their own aforementioned kinds of knowledge (Gunsela et al., 2011). In another view proposed by Kebede (2010), KM is the creation and management of an environment, which encourages knowledge to be constructed, shared, learnt, enhanced, and organized to help the organization.

Since the main factor that will bring the organizations a competitive advantage is "human", the idea that using the employees' knowledge, skills and capabilities in an efficient and effective manner will significantly contribute to achievement of the strategic targets of the enterprises has introduced the strategic human resources approach. In this context, Strategic Human Resources Practices, by way of its applications, establishes connection between the business needs and organizational activities, unite and guide the employees in line with the business strategies and provide the firms with a competitive advantage (Liao et al., 2009). Therefore, it is stated that the Strategic Human Resources Practices applications will give the enterprise with a competitive advantage, which cannot be imitated or substituted. Therefore, we may ensure that the employees act in accordance with the firm's strategies and targets, that the expected behaviors are guaranteed by means of the planned trainings, that the employees are motivated become more participant by efficient practices (Findikl1, et al. 2015). Innovation generally implies the adoption of an idea or behavior, which is new for the organization. Innovation can be in the form of a new product or service, a new production process technology, a new 
structure or administrative system, or a new plan for organizational members (Tan. \& Nasurdin, 2010). Organizational innovation is a multidimensional concept that pertains to different operations of any firm. The nature of the activities in each innovation type is different, and they necessitate various strategies. There are three pairs of organizational innovation, which are administrative and technical, product and process, and radical and incremental, that has absorbed substantial amount of attention in previous studies (Kör \& Maden, 2013).

Knowledge sharing is described as a business process that needs collective knowledge, skills and expertise, and distribution of knowledge across the organizational units (Chen \& Huang, 2009). Knowledge sharing also includes the exchange of employee knowledge, experiences, and skills throughout the organizational and the whole firm to build new mental models (Lin, 2007). Organizational members can easily reach the knowledge by sharing knowledge among themselves and/or across various units, which reduces the amount of time and investment needed to collect information. By reducing time and investment for collecting information and building new mental models, firms can transfer their valuable resources to innovation processes. Additionally, sharing and exchanging knowledge cause high level of participation in learning new knowledge, which are essential for the development innovative ideas (Chen \& Huang, 2009). Thus, knowledge-sharing processes appears to be positively associated with innovation. Based on the definitions, we may conclude that the $\mathrm{KM}$ represents a process whose processes are different from one study to another one. For instance, Davenport (1996) defines it as knowledge generation, information coding, coordination and information transfer; and Malhotra (2003) as information awareness, determination of the purposes of knowledge, implementation, dissemination, improvement and storage. Bharadwaj et al. (2005) revealed that the KM capacity of firms consists of obtaining, sharing, implementing and assessing processes. Gold et al. (2001) also addressed the KM processes in four stages; namely, information collection, conversion of information into available information (information internalization), implementation (information sharing - information assessment), and information safe-keeping. It can be said that the aspects determined by the researchers are associated with the processes in terms of information acquisition, information sharing and implementing (Chen \& Huang, 2009).

\section{Problem definition}

Today's world is full of complexity that puts organizations into serious challenges in terms of growth and excellence and managers as planners, organizers and leaders of humanity are faced with many challenges. They should be able to be superior to its competitors, at least in one field and have an advantage over them to convince their customers. In other words, they have no choice but to be innovative. To make innovation happening in organization, at first it is essential that managers have the necessary knowledge about the internal and external factors that influence on the organization. Second, knowledge has to flow freely throughout the organization. Finally, an organization must be responsible. In fact, innovation is a response. Therefore, the organization, which is responsive and agile is more likely to be more innovative. The present study is a survey on the effects of KM initiatives on innovation in the organization. So the main question of this research is to find out about the effect of KM dimensions on employee's innovation in the Agricultural Bank in Qazvin?

\section{Hypotheses}

- Knowledge Creation has significant effect on the employee's empowerment in the Agricultural Bank of Iran.

- Knowledge Storage has significant effect on the employee's empowerment in the Agricultural Bank of Iran.

- Knowledge sharing (knowledge Distribution) has significant effect on the employee's Empowerment in the Agricultural Bank of Iran.

- Knowledge Application has significant effect on the employee's empowerment in the Agricultural Bank of Iran. 
- Knowledge Creation has significant effect on the employee's Innovation in the Agricultural Bank of Iran.

- Knowledge Storage has significant effect on the employee's Innovation in the Agricultural Bank of Iran.

- Knowledge sharing (knowledge Distribution) has significant effect on the employee's Innovation in the Agricultural Bank of Iran.

- Knowledge Application has significant effect on the employee's Innovation in the Agricultural Bank of Iran.

- Employee's Empowerment has significant effect on the employee's Innovation in the Agricultural Bank of Iran.

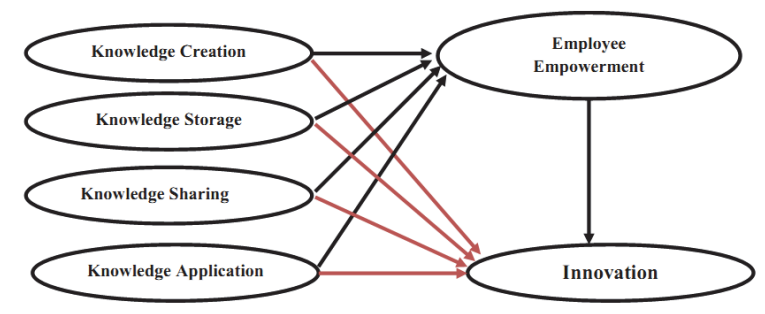

Fig. 1. Conceptual Model, adapted from (Liu \& Tsai, 2009)

Fig. 1 shows the structure of the proposed study.

\section{Research design and methods of data analysis}

This research is based on applied method and the nature of research is descriptive-survey. The population of the research are employees of Agricultural Bank of Qazvin province in Iran, which in this study, 188 patients were evaluated as the sample size. In this study, information was collected on field study and library. To gather information, self-made questionnaires have been used with regard to the dimensions and variables and the subject of the necessary validity and reliability. Cronbach's alpha coefficient was calculated at the rate of 0.917 . SPSS-22 and LISREL-8.8 software were used to analyze the collected data. In order to categorize and summarize the findings of descriptive statistics (frequency tables and charts for demographics), and to achieve the goals were used of inferential statistics.

\subsection{Theoretical framework of research}

The theoretical framework is fundamental that all research is based on. This framework is Logical, descriptive and cultured network including the relationships among the variables seeking to implement procedures including interviews, observation and review of the literature. After identifying the appropriate variables we must develop a network of relationships among the variables to be created and then tested assumptions associated with them. The theoretical framework clarifies the relationship between variables as the theoretical framework forms the basis of the literature review. This means that literature review may identify variables that are important and in fact are the findings of previous studies. The theoretical framework provides a good basis for formulating testable, reasonably and necessary hypotheses (Sekaran, 2003). In this study, we discussed and examined the impact of knowledge management on employee's innovation by mediating role of employee's empowerment in the Agricultural Bank in Qazvin. Thus, according to the literature and conceptual model, the knowledge management dimensions are independent variables and employee's empowerment is mediating variable and employee's innovation is dependent variable.

\subsection{Population and sample size}

The population consisted of 369 Agricultural Bank staff in Qazvin. For sampling, a simple random sampling method is used. Since the population in this study is limited and available, for determining 
the sample size, Cochran's sample size formula was used and according to this formula, the sample size of 188 is calculated as follows:

$$
n=\frac{N \times Z_{\frac{\alpha}{2}}^{2} \times p \times q}{\varepsilon^{2}(N-1)+Z_{\frac{\alpha}{2}}^{2} \times p \times q}=\frac{369 \times(1 / 96)^{2} \times 0 / 5 \times 0 / 5}{(0 / 05)^{2} \times(1022)+(1 / 96)^{2} \times 0 / 5 \times 0 / 5} \cong 188
$$

\subsection{Data collection tools}

To gather the information related to literature and research literature, library method is used and to collect data to confirm or refute the hypothesis of the study, a questionnaire is used.

1- General inquiries: in the general questions, we try to collect sufficient information and demographics on the respondents. This section consists of five questions (age, years of service, gender, marital status and educational level of the respondents).

2- Specific questions: This section consists of 22 questions to assess the components of knowledge management and 10 questions to assess the employee's empowerment and 6 questions to assess the employee's innovation.

3- 8 questions of 38 questions were eliminated due to their low factor loading coefficients.

The questionnaire is based on five-item Likert scale.

\section{Validity and Reliability}

Validity of the questionnaire of this study was based on content validity. The questionnaire was used according to the research hypotheses and then confirmed by experts. To estimate the reliability of the questionnaire Cronbach's alpha was used and it was equal to 0.869 . In our survey, $62 \%$ of the participants were male and $38 \%$ of them were female. In terms of marital status, $83 \%$ of them were married and $17 \%$ of them were single. Other descriptive information are summarized as follows,

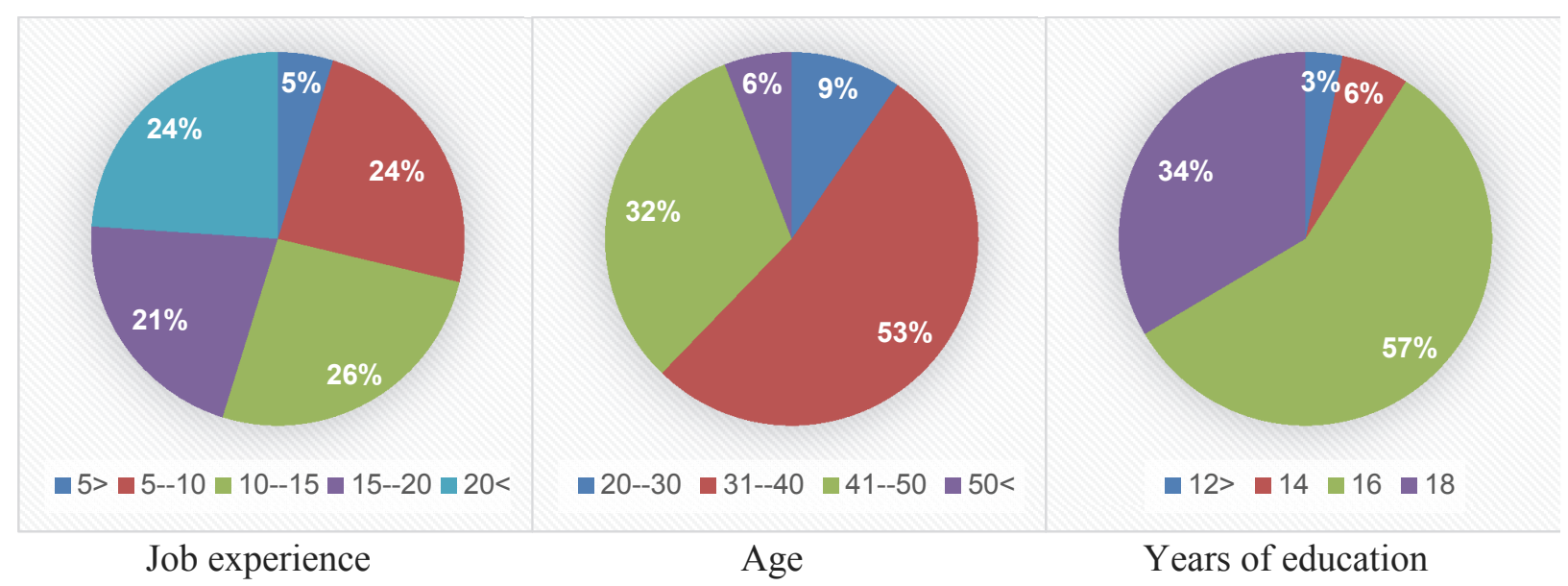

\section{Inferential statistics}

To determine the normality of data distribution of collected data, the Kolmogorov - Smirnov test was implemented and the results are summarized in Table. As we can observe from the results of Table 1, all variables are normally distributed when the level of significance is five percent. Next, we present details of the measurement of factors loadings and testing the hypotheses of the survey. The criterion for suitability factor loadings coefficients is equal to 0.5 .8 questions of 38 questions have a load factor less than 0.5. These questions must be removed for continuing analysis. After removal of these questions, all of the questions in the questionnaire have load factors greater than 0.5 that indicates the suitability of this measure. Fig. 1 and Fig. 2 shows details of our survey. 


\section{Table 1}

The results of the Kolmogorov - Smirnov test

\begin{tabular}{|c|c|c|c|c|c|c|c|}
\hline & & Creation & Storage & $\begin{array}{l}\text { Sharing } \\
\text { distribution }\end{array}$ & Application & Empowerment & Innovation \\
\hline & $\mathrm{N}$ & 188 & 188 & 188 & 188 & 188 & 188 \\
\hline \multirow[t]{2}{*}{ Normal Parameters ${ }^{\mathrm{a}, \mathrm{b}}$} & Mean & 2.9639 & 3.3096 & 3.4053 & 3.2830 & 3.1936 & 3.2012 \\
\hline & Std. Deviation & .66649 & .68515 & .76959 & .73385 & .62090 & .67606 \\
\hline \multirow{4}{*}{$\begin{array}{l}\text { Most Extreme } \\
\text { Differences }\end{array}$} & Absolute & .058 & .116 & .095 & .111 & .058 & .064 \\
\hline & Positive & .043 & .088 & .059 & .067 & .049 & .042 \\
\hline & Negative & -.058 & -.116 & -.095 & -.111 & -.058 & -.064 \\
\hline & Test Statistic & .058 & .116 & .095 & .111 & .058 & .064 \\
\hline \multicolumn{2}{|c|}{ Asymp. Sig. (2-tailed) } & $.200^{\mathrm{c}, \mathrm{d}}$ & $.000^{\mathrm{c}}$ & $.000^{\mathrm{c}}$ & $.000^{\mathrm{c}}$ & $.200^{\mathrm{c}, \mathrm{d}}$ & $.056^{\mathrm{c}}$ \\
\hline
\end{tabular}

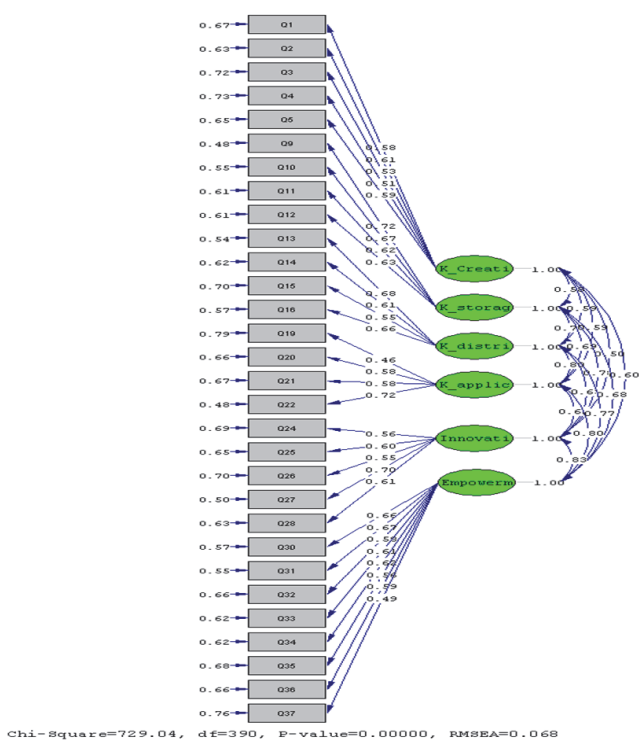

Fig. 1. Measearment model afer modification with standard coefficients

\subsection{Structural Model tests}

Structural model studies the relationships between different variables. In fact, the relationships between these variables indicate approval or disapproval hypotheses. Before entering this section, we must make sure of the model fitness.

\section{Table 2}

Control of the most important indicators in the evaluation of model fitness

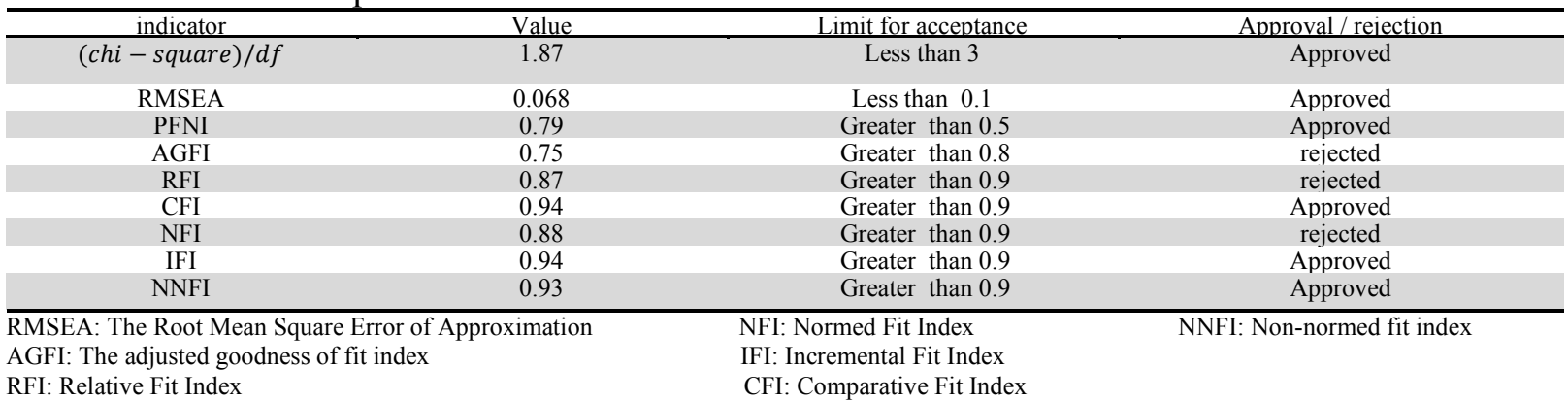

Table 2 demonstrates the summary of the statistical observations. As we can observe from the results, all statistics are within desirable levels. Fig. 3 and Fig. 4 show details of testing the hypotheses of the survey. Based on the estimated path coefficients in the structural model, the direct and indirect effects of all variables on the dependent variable are obtained and summarized in Table 3 as follows, 
Table 3

An overview of coefficients

\begin{tabular}{|c|c|c|c|c|c|}
\hline Hypotheses & Independent Variable & Dependent Variable & Impact Coefficient & t-value & Result \\
\hline 1 & Knowledge Creation & Employee's Empowerment & 0.13 & 1.27 & rejected \\
\hline 2 & Knowledge Creation & Employee's Innovation & -0.08 & -0.63 & rejected \\
\hline 3 & Knowledge Storage & Employee's Empowerment & 0.07 & 0.48 & rejected \\
\hline 4 & Knowledge Storage & Employee's Innovation & 0.63 & 3.41 & Direct \& significant Impact \\
\hline 5 & Knowledge Sharing & Employee's Empowerment & 0.28 & 1.41 & rejected \\
\hline 6 & Knowledge Sharing & Employee's Innovation & -0.30 & -1.22 & rejected \\
\hline 7 & Knowledge Application & Employee's Empowerment & 0.44 & 2.51 & Direct \& significant Impact \\
\hline 8 & Knowledge Application & Employee's Innovation & -0.22 & -1.00 & rejected \\
\hline 9 & Employee's Empowerment & Employee's Innovation & 0.86 & 3.81 & Direct \& significant Impact \\
\hline
\end{tabular}

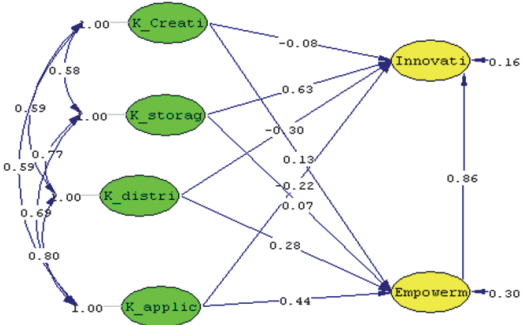

Chi-square $=729.04, d f=390, E-v a l u e=0.00000$, RMsEA $=0.068$

Fig. 3. Structural model with standard coefficients

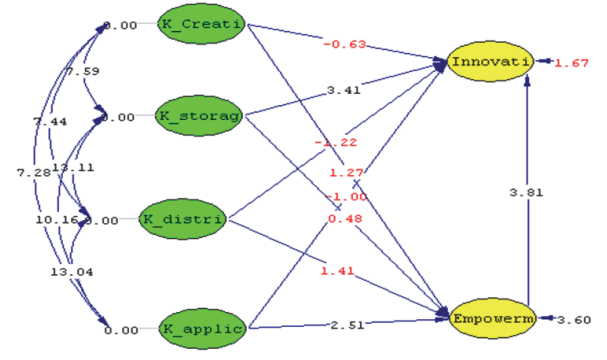

Chi-Square $=729.04, d f=390, E-v a l u e=0.00000$, RMSEA $=0.068$

\section{Conclusion and suggestions}

In this study, we have investigated the effect of KM initiatives on innovation, both directly and through employee empowerment mediator. In order to test the model, fitness indexes were studied. After a correction phase and eliminating some of the inappropriate questions in the questionnaire, goodness of fit of model was approved. After the analysis by LISREL software and software-based modifications, the results have shown that knowledge storage had direct effect on employees' innovation and knowledge application had direct effect on employee empowerment in Agricultural Bank. The results have also revealed the fact that empowerment of employees would lead to innovation by them. Other variables did not have any impact on innovation directly or through employee empowerment.

\section{References}

Akgun, A., Keskin, H., \& Gunsel, A. (2007). Communities Of Practice: An Important Actor Of Organizational Learning, From the Proceedings of III. International Strategic Management Conference. Antalya Turkey.

Alavi, M., \& Leidner, D. (1999). Knowledge management systems: Issues, challenges, and benefits. Communications of the AIS, 1(5), 1-35.

Bharadwaj, S., Bhushan, S., \& Saxena, C. (2005). Knowledge Management in Global Software Teams. Vikalpa, 30(4), 65-75.

Chen, C.-J., \& Huang, J.-W. (2009). Strategic Human Resource Practices and Innovation Performance - The Mediating Role of Knowledge Management Capacity. Journal of Business Research, 62, 104114.

Darroch, J., \& McNaughton, R. (2002). Examining the link between knowledge management practice and types of innovation. Journal of Intellectual Capital, 3(3), 210-222.

Davenport, T. (1996). Some principles of knowledge management. Strategy \& Business, 1(2), 34-40.

Fındıkl1, M., Yozgat, U., \& Rofcanin, Y. (2015). Examining Organizational Innovation and Knowledge Management Capacity The Central Role of Strategic Human Resources Practices. Procedia - Social and Behavioral Sciences, 181, 377-387. 
Gold, H., Malhotra, A., \& Segars, A. (2001). Knowledge Management: An Organizational Capabilities Perspective. Journal of Management Information Systems, 18, 185-214.

Gunsela, A., Siachou, E., \& Acar, A. (2011). Knowledge Management And Learning Capability To Enhance Organizational Innovativeness. Procedia Social and Behavioral Sciences, 24, 880-888.

Kebede, G. (2010). Knowledge management: An information science perspective. International Journal of Information Management, 30, 416-424.

Kör, B., \& Maden, C. (2013). The Relationship between Knowledge Management and Innovation in Turkish Service and High-Tech Firms. International Journal of Business and Social Science, 4(4), 293-304.

Liao, S.-H., Wu, C.-C., Hu, D.-C., \& Tsuei, G. (2009). Knowledge Acquisition, Absorptive Capacity,and Innovation Capability: An Empirical Study of Taiwan's Knowledge-Intensive Industries. International Journal of Social, Behavioral, Educational, Economic, Business and Industrial Engineering, 3(5), 338-345.

Lin, H. (2007). Knowledge sharing and firm innovation capability: an empirical study. International Journal of Manpower, 28(3/4), 315-332.

Liu, P.-L., \& Tsai, C.-H. (2009). A Study on the Relationship between Knowledge Management, Knowledge Absorption and Innovative Management Capabilities in Taiwan's High-tech Industries. International Journal of The Computer, the Internet and Management , 1-17.

Malhotra, Y. (1997). Knowledge management in inquiring organizations. 3rd Americas Conference on Information Systems, (pp. 239-295). Indianapolis.

Malhotra., Y. (2003). Is Knowledge the Ultimate Competitive Advantage? Business Management Asia, 3(4), 66-69.

Nonaka, I., \& Toyama, R. (2007). Strategic management as distributed practical wisdom (phronesis). Industrial and Corporate Change, 16(3), 371-394.

Parlby, D., \& Taylor, R. (2000). The power of knowledge: a business guide to knowledge management. Retrieved from http://www.kpmgconsulting.com/index.html

Pelit, E., \& Pelit, N. (2014). The Effects of Mobbing on Organizational Cynicism: A Study on Hotels in Turkey. International Journal of Human Resource Studies, 2162-3058.

Salisbury, M. (2003). Putting theory into practice to build knowledge management systems. Journal of Knowledge Management, 7(2), 128-141.

Sekaran, U. (2003). Research methods for business : a skill-building approach. New York: Wiley.

Tan, C., \& Nasurdin, A. (2011). Human Resource Management Practices and Organizational Innovation: Assessing the Mediating Role of Knowledge Management Effectiveness. Electronic Journal of Knowledge Management, 9(2), 155-167.

Tan., C. L., \& Nasurdin, A. M. (2010). Knowledge Management Effectiveness and Technological Innovation: An Empirical Study in the Malaysian Manufacturing Industry. Journal of Mobile Technologies, Knowledge and Society. doi:10.5171/2010.428053

Teece, D. (2007). Explicating dynamic capabilities: The nature and microfoundations of (sustainable) enterprise performance. Strategic Management Journal, 28(13), 1319-1350.

Tsai, Y. (2011). Relationship between Organizational Culture,Leadership Behavior and Job Satisfaction. Health Services Research, 1472-6963.

Von Krogh, G. (1998). Care in knowledge creation. California Management Review, 40(30), 133-154.

Watson, T. (2006). Organising and Managing Work. london: UK: Pearson.

Wiig, K. (1997). Knowledge management: Where did it come from and where will it go? Expert Systems with Applications, 13(1), 1-14.

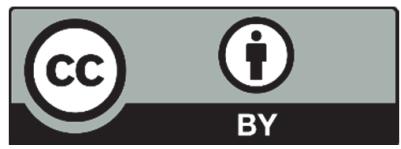

(C) 2017 by the authors; licensee Growing Science, Canada. This is an open access article distributed under the terms and conditions of the Creative Commons Attribution (CC-BY) license (http://creativecommons.org/licenses/by/4.0/). 